\title{
ALIH TEKNOLOGI PEMBUATAN CUKA KAYU SEBAGAI BAHAN DISINFEKTAN MELALUI PROSES PIROLISIS OLEH KOMUNITAS CILIWUNG DEPOK
}

\author{
Haolia Rahman ${ }^{1}$, Minto Rahayu², Muslimin, Dianta Mustofa Kamal ${ }^{4}$, Asep \\ Yana ${ }^{5}$ \\ 1,2,3,4 Jurusan Teknik Mesin, Politeknik Negeri Jakarta \\ Alamat: Jl. Prof. DR. G.A. Siwabessy, Kampus Universitas Indonesia Depok 16425 \\ $\square_{e-m a i l:} \underline{\text { haolia.rahman@mesin.pnj.ac.id }}$
}

\begin{abstract}
Ciliwung is a river that passing through two Provinces; Jawa Barat and Jakarta, whose existence often causes flooding during the rainy season. The Bamboo and wood fell into the Ciliwung River can cause blockage and can potentially make the river overflow. Komunitas Ciliwung Depok is a community that cares about the cleanliness of the Ciliwung River which has routine activities to clean the river flow from falling wood and bamboo. However, the collected bamboo and woods becomes a new problem due to less of waste management. Department of Mechanical Engineering, Politeknik Negeri Jakarta has a purpose to transform the waste of collected bamboo and wood become wood vinegar by pyrolysis process to increase the economic value of the waste. Pyrolysis is the process of condensing smoke in a cooled pipe from a combustion or carbonization of burning bamboo and wood in a furnace. The condensing smoke is called wood vinegar. Wood vinegar is the main component for disinfectants and organic fertilizers. Based on the experience and it expertise, Mechanical Engineering Department PNJ took their community service to produce pyrolysis equipment for the Community. The purpose of this activity is to transfer the knowledge and the technology of utilizing bamboo and wood waste to transform into wood vinegar through the pyrolysis process. The output of this community service is a set of pyrolysis equipment, articles in the mass media, and training videos.
\end{abstract}

Keywords-- Disinfectant, pyrolysis, wood vinegar, Ciliwung community

\begin{abstract}
Abstrak
Ciliwung merupakan sungai yang mengitari dua Provinsi Jawa Barat-Jakarta, yang keberadaannya kerap kali menimbulkan banjir disaat musim penghujan. Limbah bambu dan kayu yang ikut hanyut di Sungai Ciliwung dapat mengakibatkan tersumbatnya dan dapat berpotensi meluapnya aliran sungai. Komunitas Ciliwung Depok merupakan komuntas yang peduli akan kebersihan sungai Ciliwung yang mempuyai kegiatan rutin untuk membersihkan aliran sungai dari limbah kayu dan bambu. Namun demikian, limbah yang dikumpulkan menjadi permasalahan baru karena belum ada pengelolaan limbah yang dikumpulkan. Kegiatan Pengabdian Masyarakat Jurusan Teknik Mesin, Politeknik Negeri Jakarta Tahun 2020 dilatar belakangi oleh hal tersebut dimana memanfaatkan limbah bambu dan kayu untuk dijadikan produk yang bernilai ekonomis, yakni pembuatan cuka kayu dengan cara pirolisis. Pirolisis merupakan proses pengembunan asap dari sebuah pembakaran atau karbonisasi, limbah bambu dan kayu dikarbonisasi dengan menggunakan tungku, kemudian asap yang keluar dari tungku disalurkan oleh pipa yang didinginkan, sehingga asap terkonesasi menjadi asap cair yang disebut cuka kayu. Cuka kayu merupakan bahan utama pembuatan disinfektan dan pupuk organic. Melalui para pakar yang ahli dalam bidang desain serta pembuatan mesin pirolisis, dosen-dosen di Jurusan Teknik Mesin merencanakan melakukan pengabdian masyarakat untuk membuat alat Pirolisis bagi Komunitas Ciliwung Depok. Tujuan kegiatan ini ialah alih teknologi pemanfaatan limbah bambu dan kayu dari sungai ciliwung untuk dijadikan cuka kayu melalui proses pirolisis. Adapun luaran dari pengabdian kepada masyarakat ini adalah seperangkat alat pirolisis, artikel di media massa, dan video pelatihan.
\end{abstract}

Kata Kunci-- Cuka kayu, asap cair, pirolisis, sungai Ciliwung, disinfektan. 


\section{Pendahuluan}

Setiap masuk musim penghujan, sungai Ciliwung kerap kali meluap, sehingga mengakibatkan banjir di ibu kota. Hal ini disebabkan karena berkurangnya area resapan di sekitar sungai ciliwung dan kapasitas sungai Ciliwung yang semakin berkurang. Berkurangnya kapasitas Sungai Ciliwung disebabkan pula oleh beberapa masalah diantaranya pendangkalan dan kiriman sampah dan limbah padat dari hulu aliran sungai seperti Bogor dan Depok.

Limbah padat dan besar seperti kayu dan bambu yang hanyut pada aliran sungai Ciliwung menjadi beban tersendiri bagi pemerintah dan warga yang tinggal di sekitar sungai Ciliwung. Hal tersebut disebabkan karena kayu dan bambu dapat menyumbat dan menjaring sampahsampah lainnya sehinga berpotensi untuk menutupi aliran sungai. Untuk itu, Komunitas Ciliwung Depok (KCD) mempunyai aktivitas rutin dalam mengumpulkan limbah bambu dan kayu yang tesangkut pada aliran Ciliwung[1,2]. Namun demikian, permasalahan baru muncul dilaka banyaknya bambu dan kayu yang dikumpulkan tidak dapat diolah seperti ditunjukan pada gambar 1 .

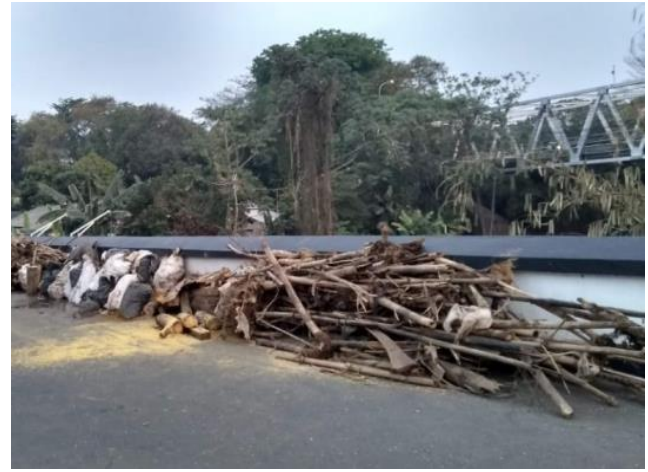

Gambar 1. Tumpukan kayu dan bambu yang dikumpulkan dari aliran sungai Ciliwung oleh KCD

Kegiatan Pengabdian Kepada Masyarakat Jurusan Teknik Mesin dilatarbelakangi dari hasil diskusi dosen Jurusan Teknik Mesin dengan KCD tentang belum adanya manajemen pemenfaatan limbah bambu dan kayu yang dikumpulkan. Dari diskusi tersebut menghasilkan sebuah perencanaan berbasis pemanfaatan limbah bambu dan kayu, untuk dijadikan produk yang menghasilkan nilai ekonomi.

Berdasarkan penelitian, bambu dan kayu dapat diproses untuk dijadikan cuka kayu melalui proses pirolisis[3]. Cuka kayu mempunyai nilai ekonomis yang manfaatnya dapat digunakan sebagai bahan dasar desinfektan, pengawet makanan, pembasmi hama dan penyakit tanaman, pupuk cair organic[4], penyubur tanaman, desinfektan dan inhibitor mikroorganisme serta pencegah jamur dan bakteri[5].

Pirolisis merupakan proses pengembunan asap dari pembakaran atau karbonisasi[6]. Dalam hal ini, limbah bambu dan kayu dikarbonisasi dengan menggunakan tungku, kemudian asap yang keluar dari tungku disalurkan oleh pipa yang didinginkan, sehingga asap terkondensasi menjadi asap cair yang disebut cuka kayu. Melalui pakar-pakar yang ahli dalam desain serta pembuatan mesin pirolisis, dosendosen di Jurusan Teknik Mesin merencanakan melakukan pengabdian masyarakat untuk membuat alat Pirolisis bagi Komunitas Ciliwung Depok.

Dengan dengan demikian, Tim Dosen Jurusan Teknik Mesin mengapresiasi dan mendukung Mitra Pengabdian yakni KCD yang telah berupaya mengurangi limbah sampah kayu dan bambu. Dengan dilaksanakannya pelatihan dan hibah alat tersebut, diharapkan agar limbah dapat dimanfaatkan dengan tepat serta limbah tidak menumpuk begitu saja karena dapat mencemari lingkungan. Jurusan Teknik Mesin telah mengupayakan pelatihan tentang tata cara pemanfaataan limbah bambu dan kayu dapat diproses untuk dijadikan cuka kayu melalui proses pirolisis agar mitra dapat melakukan pemanfaatan limbah kayu dan bambu secara berkelanjutan. 


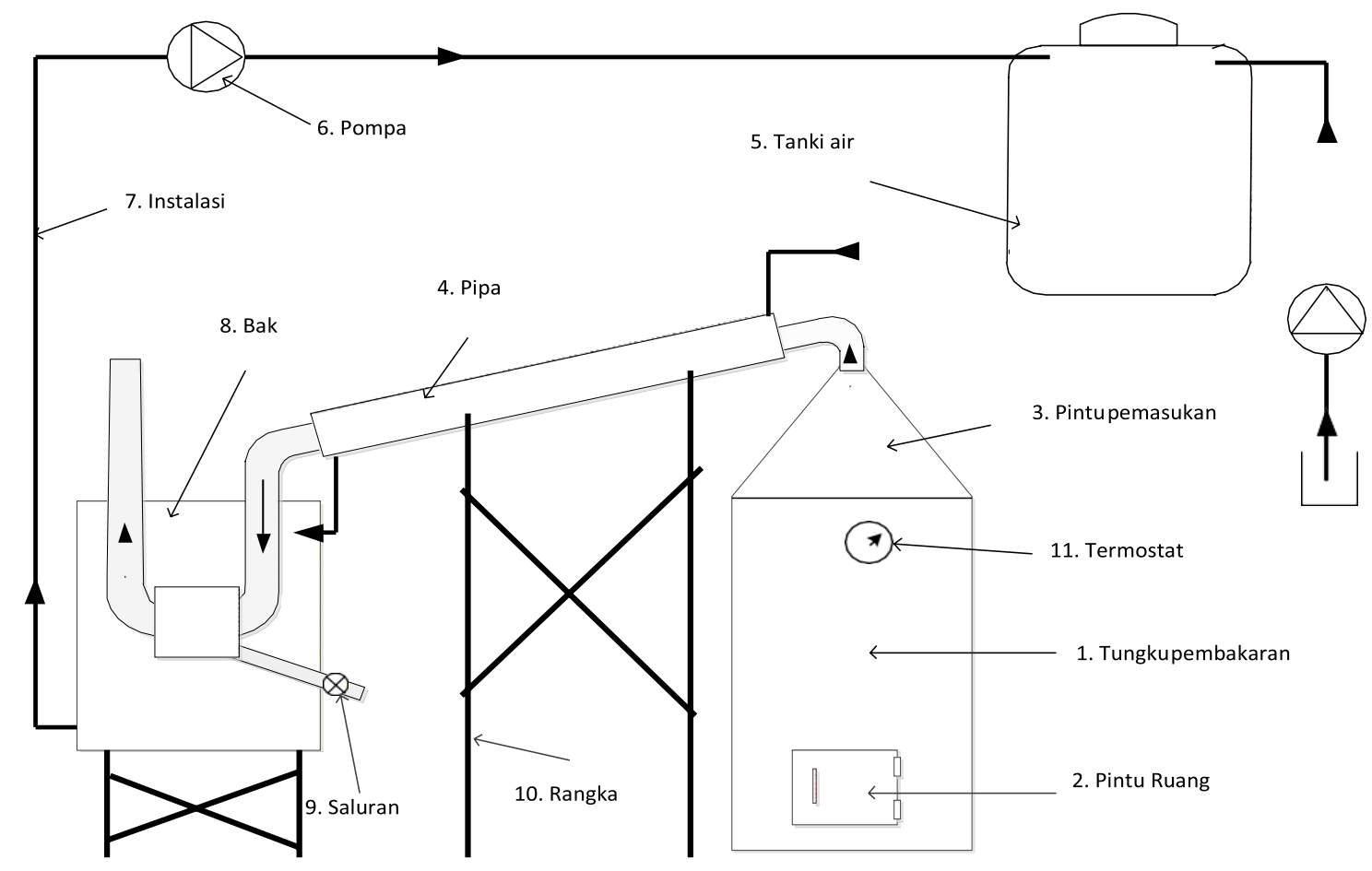

Gambar 2. Rancangan alat pirolisis

\section{Metode Pengabdian}

\section{Persiapan dan survey}

Persiapan kegiatan pengabdian masyarakat ini diawali dengan diskusi antara dosen PNJ dengan KCD dalam perencananan teknis alat dan penempatan alat. Pada tahapan ini juga, survey dilakukan ke dua tempat. Tempat pertama adalah lokasi dimana alat pirolisis ditempatkan yiutu di sekitar area Dermaga KCD - Kota Kembang, Jl. Boulevard, GDC. Survey berikutnya adalah survey studi banding alat pirolisis yang sudah dibuat dan dapat memproduksi asap cair yaitu di Puslitbang Hasil Hutan Bogor.

\section{Pembuatan alat pirolisis}

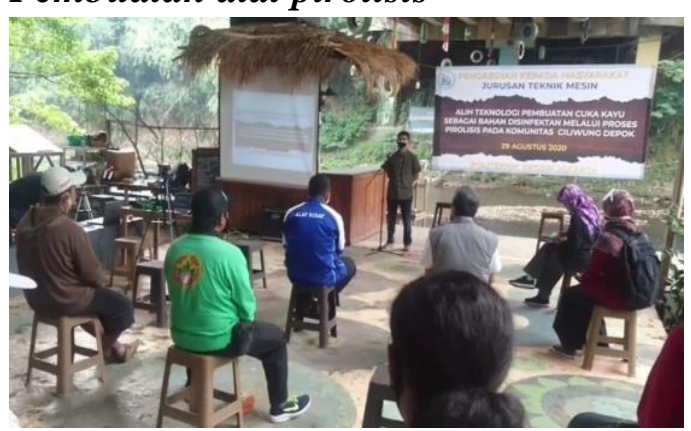

Gambar 3. Kegiatan pengabdian masyarakat
Pembuatan alat pirolisis mengacu pada gambar kerja yang sudah direncakanan seperti terlihat pada gambar 2 . Pembuatan alat pirolisis ini difabrikasi di beberapa tempat yang salah satunya adalah bengkel Teknik Mesin PNJ. Waktu pengerjaan alat ini selama 1 bulan yang meliputi perencanaan, pembelian alat dan bahan, fabrikasi dan penempatan.

\section{Pelaksanaan pengabdian}

Kegiatan Pengabdian Kepada Masyarakat Jurusan Teknik Mesin dilaksanakan di Area Dermaga KCD Kota Kembang, Jl. Boulevard, GDC, Depok. Kegiatan ini mengundang komponen masyarakat yang berasal dari sekitar lokasi diantaranya dari kelurahan Pancoran Mas, Depok, dan Ratu Jaya. Selain itu kegiatan ini mengundang narasumber pakar asap cair, Kadis Lingkungan Hidup dan Kebersihan Kota Depok, dan partisipan dari PNJ yang hadir on-line maupun off-line. Kegiatan pengabdian masyarakat ini dapat dilihat pada gambar 3 . 


\section{Hasil Dan Pembahasan}

Kegiatan dari pengabdian masyarakat ini dilaksanakan pada tanggal 29 Agustus 2020, berupa serangakaian kegiatan yang dipandu oleh pembawa acara yang merupakan salah satu panitia yaitu Ibu Minto Rahayu, SS. MSi. Kegiatan ini diawali oleh sambutan ketua pelaksana

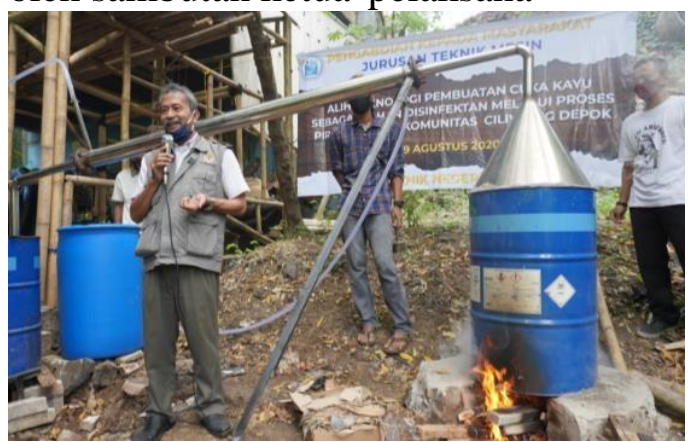

Gambar 4. Pelatihan penggunaan alat pirolisis

kegiatan, Bapak Haolia Rahman, Ph.D., yang menjelaskan laporan kegiatan, kronologis terlaksananya kegiatan pengabdian masyarakat, dan tujuan dari pengabdian kepada masyarakat. Kemudian, tuan rumah yang merupakan perwakilan KCD Bapak Sahroel menarasikan perjalanan kerjasama antara PNJ dengan KCD. Penyampaian berikutnya oleh Ketua Jurusan Teknik Mesin bapak Dr. Eng. Muslimin, S.T., M.T. yang menjelaskan tugas utama dari dosen yang salah satunya adalah pengabdian masyarakat.

Pada kegiatan pengabdian masyarakat ini, pengetahuan mengenai manfaat dari asap cair, sejarah serta cara membuatnya dijelaskan secara rinci oleh nara sumber yang ahli dalam mendesain alat pirolisis yaitu Prof. Dr. Gustan Pari, BSc. Dipl.IV, M.Si. yang dilanjutkan dengan pelatihan menggunakan alat pirolisis seperti terlihat pada gambar 4 . Kegiatan terakhir pada pengabdian masyarakat ini adalah serah terima peralatan hibah yang berupa seperangkat alat pirolisis oleh Ketua Jurusan Teknik Mesin dengan ketua KCD seperti terlihat pada gambar 5 .

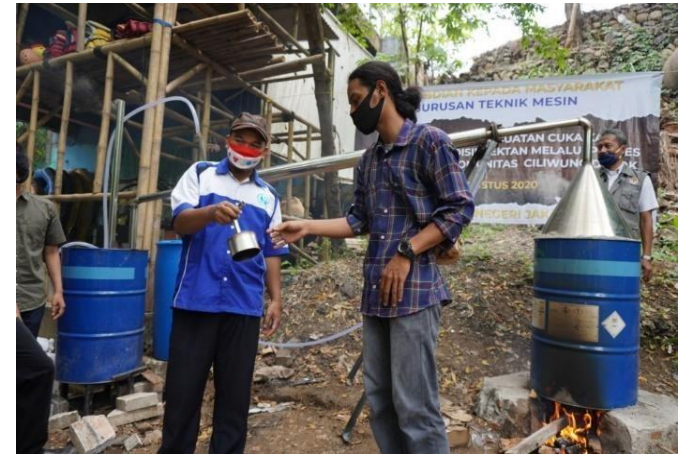

Gambar 5. Serah Terima Alat pirolisis

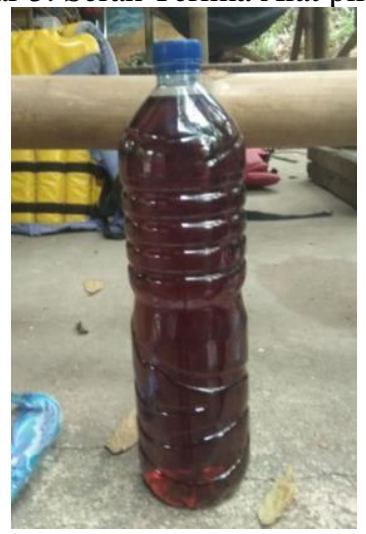

Gambar 6. Asap cair hasil dari proses pirolisis limbah bambu dna kayu

Hasil dari pelatihan tersebut yakni terciptanya masyarakat yang handal dalam memanfaatkan limbah bambu dan kayu untuk dijadikan produk cuka kayu. Cuka kayu yang di peroleh telah dimanfaatkan oleh masyarakat yang mengikuti kegiatan alih teknologi ini diantaranya; sebagai bahan disinfektan, pengawet makanan, pembasmi hama dan penyakit tanaman, pupuk cair organik, desinfektan dan pencegah jamur dan bakteri. Hasil dari asap cair yang diperoleh dapat terlihat pada gambar 6 .

Program ini sangat bermanfaat ganda baik bagi dosen-dosen jurusan teknik mesin, KCD dan masyarakat sekitar. Bagi dosen di Jurusan Teknik mesin, program ini merupakan tantangan dan bentuk mengaplikasikan ilmu pengetahuan yang telah dimiliki. Sedangkan bagi Komunitas, program ini dapat meningkatkan nilai ekonomi limbah yang dikumpulkan, dapat mengurangi limbah yang dikumpulkan dan pengalaman memanfaatkan teknologi tepat guna. 


\section{Kesimpulan}

Berdasarkan hasil pelaksanaan kegiatan pengabdian kepada masyarakat Jurusan Teknik Mesin, Politeknik Negeri Jakrta Tahun 2020 dengan tema "Alih Teknologi Pembuatan Cuka Kayu Sebagai Bahan Disinfektan Melalui Proses Pirolisis Oleh Komunitas Ciliwung Depok" adalah sebagai upaya untuk meminimalisir limbah sampah, terutama kayu dan bambu yang mengotori serta mencemari sungai Ciliwung. Terdapat luaran kegiatan yang akan menjadi tanggung jawab tim pengabdian kepada masyarkat disimpulkan bahwa kegiatan ini memberikan dampak baik bagi mitra yakni para peserta memiliki pengetahuan dan skill tentang pembuatan cuka kayu sebagai bahan disinfektan melalui proses pirolisis yang relatif mudah sehingga para peserta merasa tidak ada kesulitaan untuk mempraktikkannya. Adapun tingkat kepuasan dari para peserta sangat tinggi dan baik, terutama dalam hal tata cara pembuatan cuka kayu sebagai bahan disinfektan melalui proses pirolisis, penggunaan alat yang praktis tidak terlalu memakan banyak biaya dan tidak memakan banyak tempat karena alatnya sederhana ramah lingkungan.

\section{Ucapan Terima Kasih}

Penulis mengucapkan terima kasih kepada ketua UP2M PNJ beserta jajarannya yang telah memberi dukungan terhadap keberhasilan pengabdian ini. Kegiatan pengabdian mayarakat ini dibiayai oleh DIPA Politeknik Negeri Jakarta, dengan omor kontrak: 66/PL3.18/SPK/2019, tanggal 15 Juni 2020. Ucapan terima kasih juga disampaikan kepada para dosen dan admin Jurusan Teknik Mesin PNJ, anggota KCD, dan Prof. Dr. Gustan Pari, BSc. Dipl.IV, M.Si.

\section{Daftar Pustaka}

[1] Daniel Mambo Tampi, Jachrizal Sumabrata and Linda Darmajanti, Environmental lovers group: a networking of Ciliwung Depok Community, IOP Conference Series: Earth and Environmental Science, Friendly City 4 'From Research to Implementation For Better Sustainability', Medan, Indonesia, 2017, Vol. 126.

[2] Daniel Mambo Tampi, Jachrizal Sumabrata and $\mathrm{N} H$ Kinan, A Group in Urban: The Social Capital of Ciliwung Depok Community (KCD). IOP Conference Series: Earth and Environmental Science, International Conference on Climate Change: Challenges and Opportunity on Environment Degradation Researches, Surakarta, Indonesia, 2017, Vol. 129.

[3] Sri Komarayati, Santiyo Wibowo, Karakteristik asap cair dari tiga jenis bambu, Jurnal Penelitian Hasil Hutan, 2015, Vol 33 (2).

[4] Sri Komarayati, Gusmailina Gusmailina, Gustan Pari, Arang Dan Cuka Kayu : Produk Hasil Hutan Bukan Kayu Untuk Meningkatkan Pertumbuhan Tanaman Dan Serapan Hara Karbon, Journal article Jurnal Penelitian Hasil Hutan, 2013, Vol. 31 (1), 49-62.

[5] Wise. 1944. Wood Chemistry. Reinhold Publishing. New York.

[6] Colomba Di Blasi, Gabriella Signorelli, Carlo Di Russo, and Gennaro Rea, Product Distribution from Pyrolysis of Wood and Agricultural Residues, Industrial \& Engineering Chemistry Research, 1999, Vol. 38. 
